\title{
AN APPRAISAL OF THE TAX EVASION AND TAX AVOIDANCE SYSTEM IN INDONESIA
}

\author{
Rahmawati \\ UIN Syarif Hidayatullah Jakarta \\ Saifullahi Shehu Ibrahim \\ International Islamic University Malaysia
}

\begin{abstract}
Tax avoidance and evasion are pervasive in all countries. This paper, first review a literature that integrate the tax avoidance and evasion into overall decision problem faced by government. The second, reviews the issue of corruption and bureaucracy, there is a link between tax evasion and corruption. This study uses literature to analyze the cause and the effect of tax evasion and tax avoidance to environment. Finally, this paper will examine the effect of perceived corruption in government on tax evasion and how should the tax system in Indonesia face the tax evasion problem. The government attempts to improve the tax compliance in Indonesia with comprehensive regulation of the schemes of tax avoidance schemes. Therefore, it need a specific antiavoidance rules in Indonesian tax law.
\end{abstract}

Keywords: Tax Avoidance, Tax Evasion, Tax System

ABSTRAK: Penghindaran pajak dan penggelapan yang meresap di semua negara. Makalah ini, pertama meninjau literatur yang mengintegrasikan penghindaran pajak dan penggelapan dalam masalah keputusan keseluruhan yang dihadapi oleh pemerintah. Yang kedua, ulasan isu korupsi dan birokrasi, ada hubungan antara penggelapan pajak dan korupsi. Penelitian ini menggunakan literatur untuk menganalisis penyebab dan efek dari penggelapan pajak dan penghindaran pajak dengan lingkungan. Tulisan ini akan menguji pengaruh korupsi di pemerintah pada penggelapan pajak dan bagaimana seharusnya sistem pajak di Indonesia menghadapi masalah penggelapan pajak. Upaya pemerintah untuk meningkatkan kepatuhan pajak di Indonesia dengan regulasi yang komprehensif dari skema penghindaran pajak. Oleh karena itu, perlu spesifik aturan anti-penghindaran dalam hukum pajak Indonesia.

Kata kunci: Penghindaran Pajak, Penggelapan Pajak, Sistem Perpajakan

\footnotetext{
${ }^{1}$ Draft pertama: 20 Desember 2014; Revisi: 18 Januari 2015; Diterima: 7 Februari 2015 Penulis dapat dikontak melalui: wati_dahyar@zahoo.com
} 
Rahmawati: An Appraisal of the Tax Evasion..

\section{INTRODUCTION}

Tax evasion and tax avoidance in most developing countries is so rampant, and the scenario is much worsened by the fact that not many of these governments have made an effort to measure the ethical reasons that tax payers give, the extent of this problem and at the same time analyse its impact. Hence, when required revenue for smooth government operation cannot be raised, these countries often times resort to increase tax rates or borrowings which may not only crowd out the private sector of their economies but also lead them to debt traps (Chiumya, 2006). On the other hand, tax evasion has the effect of distorting the principle of perfect market resource allocation and income redistribution. This can lead to economic growth stagnation and far much reaching socio-economic repercussions. Thus, there is the need to understand the behaviour of tax payers and the reasons that cause such specific behaviour.

However, the taxpayer noncompliance has invariably been the issue of deep concern all over the world. Both developed and developing countries focus on addressing the shortcoming of their respective tax laws thereby, tackling the problems of avoidance and evasion in the respective tax environment. The issue here is in dealing with tax avoidance and evasion, this method might be seen as game oriented (considering the basic concept of tax evasion and tax avoidance based on game theory). In the game theory two strategies actors are involve; a revolutionary agent (lenin) and a defender of the status quo (Tsar) assumed to control the state of the phenomena. In taxation treatment, government levy and collect taxes. However, citizens dislike taxation because it reduces their disposable income and they have an opportunity to resist paying taxes. To forestall the inclination towards tax resistance, the status quo defender (government) imposes a penalty upon such behaviour (Mayer, 1989).

In other to ensure that adequate revenue is generated for the government development projects and provision of sufficient infrastructure and necessary amenities, it is important to know the attitudes of the citizenry towards the collection of taxes. In the light of this, the paper set out to achieve these objectives: (i) to examine the perceived seriousness of tax evasion; (ii) to investigate the perception of taxpayers to the payment of taxes on ethical reasons; (iii) to examine the consequence of perceived corruption in government on tax evasion. More so, in order to achieve these objectives the following questions are set to answers; (i) what are the reasons for tax evasion and avoidance? (ii) Tax system in Indonesia, (iii) The Assessment Tax Evasion in Indonesia.

This paper considers the effects of tax avoidance and evasion on the financing of development project in these countries. It is argued that development projects require developing countries to approach fiscal independence, and that the annual cost of tax leakages is well in excess of aid flows.

\section{THEORITICAL FRAMEWORK AND HYPOTHESIS DEVELOPMENT}

\section{Tax Revenue}

Thus, a major source of fund for any government is the tax revenue. (Asher, 2001 and Soyode \& Kajola, 2006) The World Bank (2000) noted that taxes are a compulsory transfer of resources to the government from the rest of the economy. They may be levied in cash or inkind (for example, involving mandatory labour), and they can be explicit or implicit. Other classifications of taxes are Direct or Indirect (Classification by Incidence) and Proportional, Progressive \& Regressive (Classification by Burden of Distribution). Adeyeye (2004) described tax as a liability on account of the fact that the tax payer has an income of a minimum amount and from certain specified source(s) or that he owns certain tangible or intangible property or that he is engaged in certain economic activities which have been chosen for taxation. Therefore, the individual contributes in some quantum measure to the 
fund available for use by government in providing necessary infrastructure for her citizens. (The World Bank, 2000; Adeyeye, 2004:18; Soyode and Kajola, 2006).

More so, paying taxes is perhaps the most fundamental way in which private and corporate citizens engage with broader society. It is therefore curious that tax minimization through elaborate and frequently aggressive tax avoidance strategies is regarded as one of the prime duties that directors are required to perform on behalf of their shareholders. It is even more curious that the debate about corporate responsibility, which has touched on virtually every other area of corporate engagement with broader society has scarcely begun to question companies in the area where their corporate citizenship is most tangible and most important.

\section{The Concept of Tax Evasion and Tax Avoidance}

Tax avoidance happens when an individual's manipulation of his affairs within the law so as to reduce his tax liability. On The other hand, tax evasion is illegal manipulation to reduce tax. However, accountants are the architect to tax avoidance with tax planning and tax mitigation (James and Nobes, 1997). Thus, tax is a cost of doing business so, naturally, a good manager will try to manage this cost and the risks associated with it. This is an essential part of good corporate governance (Irish Times, March 2004). This assertion was being disputed by Christensen et al, (2004) on the following justifications: Firstly, tax cannot be considered as a normal cost of production of either goods or services since tax avoidance does not in any way lead to improved production efficiency (the term 'tax efficiency' used by the tax accounting practitioners is intentionally misleading in this respect). Directors who pursue aggressive tax avoidance strategies automatically place businesses that adopt an ethical stance on tax at a commercial disadvantage even if their production processes are technically more efficient.

Secondly, paying tax can only be regarded as a business risk when directors choose to adopt aggressive tax planning strategies, and the comment is revealing of a cavalier attitude towards social responsibility. Thirdly, directors who take medium or high risk tax avoidance strategies do so in the knowledge that this will inflate price / earnings ratios, and that intervention by tax authorities is likely to lead to a downwards re-valuation. In most cases they claim to be able to manage this risk by making appropriate provision for deferred taxation, but this possibility is not even understood by investment analysts, which introduces the possibility that the pension funds of tens of millions of people have been systematically over-valued. This cannot therefore be regarded as 'an essential part of good corporate governance (Christensen et al, 2004).

Lastly, the Corporate Responsibility agenda is driven by demand for an ethical approach to doing business. It is not possible to be ethical in one area of business conduct and to act otherwise in another area, and companies that function in this way reveal disconnect in their core organizational values. Research by PricewaterhouseCoopers (PWC, 2003) has identified corporate governance as an important area of concern for institutional investors, with issues such as reduction of corruption, collusion, nepotism; inadequate disclosure and insufficient transparency of financial statements; inadequate enforcement of existing rules, and a lack of clear separation of company ownership and management, all being seen as key areas of institutional concern. Nonetheless, the seemingly related areas of compliance with taxation obligations, not using aggressive tax avoidance techniques and transparency of reporting of tax planning measures are not mentioned in the PWC report on good governance. Nor are they mentioned in the AAroooS Assurance Standard, launched in March 2003 by UK-based Accountability to promote corporate accountability for sustainable development (Christensen et al, 2004). 
Moreover, the following factors influences the tax compliance decision: expected utility, detection probability, source/level of income, level of fines, tax morale, trust in organizations, social norms, peer effects, religiosity, power of deterrence mechanism, perceived fairness of tax system (Ritsatos, 2014). Moreover, attitudes play important aspects when deciding to evade tax such as tax moral. Moral taxpayers deviate systematically and predictably with respect to effects of increasing tax rates, detection probabilities and fines on tax evasion (Prinz , 2010). There are five characteristic of tax payers such as loyal taxpayer, loyal opportunistic taxpayer, disloyal opportunistic tax payer, and disloyal taxpayer (Prinz , 2010). Each tax payer type have different value in declared their income and different taxpayers' reactions to detection probabilities and fines. The distinction between loyal and loyal as well as between opportunistic and non-opportunistic taxpayers seems to be decisive with respect to tax evasion. Opportunistic behaviour of taxpayers is a major problem with respect to tax evasion. Tax evasion influenced by increase of tax rate, the taxable wage, the detection probability and the fine (Prinz, 2010). Based on (Slehat, 2009), he examine that there is a positive significant relationship between corruption and bribery, tax rate, penalty, probability of detection, fairness of tax system and government, religion and ethics. Moreover, the level of education and level of income may significantly influence the tax evasion.

Tax evasion and tax avoidance give negative consequence called anti - social practices. Anti-social financial practices, this will leads to poor development. Therefore a scholar must give attention on the role of accountancy firms in facilitating tax avoidance, evasion and corruption (Atosanya, 2014). Thus, for a positive change that the government need to curb anti-social financial practices with political will and law of enforcement. Based on Atosanya research (2014), tax evasion and avoidance are caused by (i) Lack of structural development, (ii) Lack of data bases, (iii) Profit motives and complete failure of moral and ethical value, (iv) Lack of accountability and transparency, (iv) Bad leadership

Individual and corporate tax payer tend to evade tax and a deliberately commit tax frauds through the manipulation of financial statement such as under-reporting revenue and over stating expenses (Azrina \& Lai ling, 2014). Increasing in tax avoidance tends to reduce the level of firm value and corporate transparency interacts with tax avoidance and acts as the moderator variable between tax avoidance and corporate value (Chen, Wang, \& Tang, 2014). Therefore, corporate governance should be an important determinant of the valuation of corporate saving. The government must show will fullness and an affirmative act towards tax avoidance.

However, tax audit seeks to ensure substantial taxpayer compliance with the tax law and to make certain that taxpayers are paying the amount of tax refer by the tax law. This is to protect the loyal taxpayer against disloyal who try to pay too little, whether that gain comes from computational accident, confusion about the law or an effort to cheat. The audit works varies between taxpayer passive and taxpayer active collection schemes. Where collection is taxpayer passive, the audit assesses the performance of tax administrations. Where collection is taxpayer active, audit seeks to include voluntary compliance and to protect honest taxpayers. The auditing of the taxpayer's books is the usual means whereby respect for the tax service in finding and punishing evasion is developed (Mikesell, 2002).

\section{RESULT \& DISCUSSION}

\section{The perceived seriousness of tax evasion}

Tax evasion results in extremely severe damage to government and taxpayers alike, in terms of macroeconomic effects, tax evasion therefore can significantly reduce government revenues, unless countered by higher tax rates than otherwise would apply (Simmons \& Cheng, 1996). Then tax evasion will affect the public expenditure, which in turn will reduce 
the projects and investment and may have led to economic recession, as well as disability of targets for financing economic development, and project management of the state. In addition, tax evasion would disrupt the principle of tax equity distributed among income holders, because some taxpayers may escape their profits wholly or partially from tax payment, while others will pay, and that will increase their financial burden, because the state will have to raise the tax rate for not reaching to the to the expected financial toll (Elgaroshi \& Samat Musa, 2013).

In addition, tax evasion has the effect of distorting the principle of perfect market resource allocation with rippling effects on the state of infrastructure and income redistribution. This can lead to economic growth stagnation and far much reaching socio economic repercussions. (Fagbemi, Uadiale, \& Noah, 2010). Therefore, tax evasion is one of the maker social problems inhibiting development in developing countries and eroding the existing welfare state in developed economics world (Atosanya, 2014).

\section{Investigate the perception of taxpayers to the payment of taxes on ethical reasons}

Tax evasion in most developing countries is so rampant and the scenario is much worsened by the fact that not many of these governments have made an effort to measure the ethical reasons that taxpayers give.

Literature provides a link between tax evasion and corruption. Level of corruption and tax evasion depends on such factors as wealth of the tax payer and the wage of the tax officer. Where government to reduce bureaucracy and increase control of corruption, it will increase tax compliance. When the state create a tax environment unburdened by inefficiencies of bureaucracy and corruption of tax compliance to be effective. This is crucial for developing countries where the economic development can be drastically hampered by the lower public revenues due to lack of compliance. The reason why people pay taxes and over predict noncompliance. Tax non -compliance is a passive phenomenon in all societies. There is good evidence of shadow economy, internationally. The crux of the problem in shadow economy is the fact that individuals are behaving dishonesty by providing false information. When reviewing the literature on the ethics of tax evasion from various religious perspectives and with a focus on the question of whether tax evasion is unethical if the payments would go to an evil or corrupt state (Picur \& Belkaouli, 2006).

Citizen's belief that tax evasion is common among people they know is positively related to their acceptance of tax evasion and that tax evasion is viewed as a more acceptable activity by lower than higher income groups and by manual workers than managers, executive and professionals (Simmons \& Cheng, 1996). In term of ethical view, citizens clearly felt that tax evasion was unacceptable. To evade in entire income appears to more acceptable than stealing a newspaper (Simmons \& Cheng, 1996).

There are three opinions on the ethics of Tax Evasion such as:

a. The unethical opinion, there are three belief underlying such as belief that individuals have a duty to the state to pay whatever taxes demand, the rationale for unethical duty to pay taxes is because the individual has a duty to other community.

b. The anarchist opinion, means that there is never any duty to pay taxes because the state is illegitimate, a mere thief that has no moral authority to take anything from anyone. The anarchist does not address the ethics of tax evasion directly but rather discusses the relationship of the individual to the state. In essence, taxation is seen as theft by this group of the people.

c. The circumstance opinion, tax evasion might be justified in certain circumstances such as when tax causes price to increase and where tax is on income, with destroy incentives (Fagbemi, Uadiale, \& Noah, 2010). 
Tax evasion is ethical sometimes. Therefore, the responsiveness of government in terms of accountability, human right treatment and optimal tax rate play a significant role in the payment of taxes by this group of tax payers.

Tax evasion may be ethically justified if the tax system is perceived as being unfair the government abuses human rights, tax funds wind up in the pockets of corrupt politicians, tax rates are too high or there is inability to pay (Mc Gee \& Gelman).

\section{The effect of perceived corruption in government on tax evasion.}

The causes of corruption and occurrence activity are usually found in the interaction of individual and social structures such as public choice, "bad apple", organisational culture, clashing moral values, the ethos of public administration and correlation theory (Otusanya O. J., 2011). The level of tax evasion when government is corrupt significantly higher when it related on the government discrimination, unjust treatment and tax affordability. The perceived government corruption can make taxpayers to evade tax, tax evasion may continue to be widespread. Government can try to deter tax non-compliance through a large and strong bureaucracy. The impact of a large bureaucracy is the increase of bureaucratic corruptions. Both large bureaucracy and bureaucratic corruption are likely to reduce the tendency of individuals in a given state to accept and trust their government in general and comply with tax burden. Bloated bureaucracy. Creates an unfavourable tax.

Table 1. Bloated bureaucracy

\begin{tabular}{|l|c|c|c|}
\hline & Level of compliance & Bureaucracy. & Control of Corruption \\
\hline Indonesia & 2,53 & 17,6 & $-0,79$ \\
\hline Malaysia & 4,34 & 19,7 & 0,62 \\
\hline South Africa & 2,40 & 30,4 & 0,29 \\
\hline
\end{tabular}

Source: (Picur \& Belkaouli, 2006).

From above table it shows that tax compliance is measured by an assessments of the level of tax compliance. The three scores at the box shows that Malaysia is the highest of tax compliance. Bureaucracy is measured by the percentage of government expenditure over gross domestic product. South Africa has the highest of bureaucracy compared to Indonesia and Malaysia. Corruption is measured by a control of corruption score. Malaysia shows a higher index compared to Indonesia and South Africa. It explain that Malaysia has a lower of corruption.

Government may elect to control corruption to create conditions more conducive to tax compliance. A higher index of indicates lower corruption and higher control of corruption. Tax compliance is highest in the countries characterised by high control of corruption and low size of bureaucracy. Therefore the powerful deterrent is the creating of tax morale or climate where citizens are protected from corruption and bloated bureaucracy (Picur \& Belkaouli, 2006).

Corruption is associated with activity of executive, legislative and judicative, bureaucracy and public officials. It outcomes are associated with loss of taxes, public revenues economic devastations, lack of investment in public goods, the emergence of gangs and private armies, a loss of faith in law and institutions a poor quality of life and even a decline in average life expectancy (Cristian \& Hamptom, 2005).

Moreover, existing literature indicates that tax avoidance is clearly damaging the economy of developing countries, harmful tax practices are an even greater problem for economies developing countries. In the absence of powerful and sophisticated tax authorities as obtained in developed countries, it is relatively easy for big businesses and 
political elites to erode the potential tax base. Moreover, it has becomes clear that western banks and finance businesses profit greatly from facilitating and sheltering this process. According to one leading development NGO, the revenue losses to developing countries from the effects of tax competition and from non-payment of tax on flight capital amounts to at least US $\$ 50$ billion annually (Oxfam, 2000).

More so, the studies by Sikka \& Hampton (2005) and Olatunde (2007) stated that tax evasion is another major social problems inhibiting development in developing countries and eroding the existing welfare state in developed economies in the world. This has led to a growing attention among policy makers, western countries, international agencies and scholars. However, little attention has been placed on the ethical issues of tax evasion in Nigeria. Particularly, research into the ethics of tax evasion in Nigeria is of little existence. Hence, an enviable society can only be visible when domestic revenue can be mobilized for her social obligation to the citizens. (Sikka \& Hampton, 2005 and Olatunde, 2007). Tax evasion in most developing countries is so rampant, and the scenario is much worsened by the fact that not many of these governments have made an effort to measure the ethical reasons that tax payers give, the extent of this problem and at the same time analyze its impact.

More so, for the government policy to combat tax evasion and tax avoidance, it may firstly consider to establish the underlying objectives (Cobham, 2005). Policymakers cannot be motivated by a simple moral position (e.g. that certain behaviour is 'bad') without exploring the implications more fully. It is not clear on the face of it, for example, what the moral distinction should be between the following: tax minimisation strategies ranging from transfer pricing to the creation of; special purpose vehicles or nominal transfer of headquarters; under-reporting; bribery of tax officials; refusal to pay; lobbying of governments to reduce tax liability or effective incidence of tax system; lobbying by multinationals of 'home' country governments to pressure 'host' country governments to the same effect; or lobbying via international institutions (IMF, World Bank, WTO) to achieve similar effects.

\section{The reasons for tax evasion and avoidance}

Elgaroshi \& Samat Musa (2013) stated, that there are multiple reasons for tax evasion based on:

a. Legal reasons, it is noted that the Indonesia tax legislation features instability to some extent, especially when compared to other legislations. The lack of knowledge about tax law is one the big problem that increased tax evasion. Need to increase the law of enforcements.

b. Ethical reason, moral level is an important reason in tax evasion, if weak it will affect the awareness level of taxpayers, leading to a lack of attention to public interest, and the lowers sense of responsibility to increase performance of tax comes from fear, not conviction.

c. Administrative reasons

Need to combine theoretical and practical parts to increase tax administration (Elgaroshi \& Samat Musa, 2013).

\section{The Indonesian Tax System}

Indonesia's economy has steadily improved since crisis time. The country has been growing steady in the last few years mostly due to high domestic consumption and growth in exports of manufactured products and commodities. Per capita income has been backed to pre-crisis level since 2004 and growth rate now accelerating to $5.8 \%$ pa. However, the problems of Unemployment both opens and under employment are still higher than pre 
crisis. Poverty trends are moving away of the paths. Indonesia's labor productivity is relatively weak even in key sectors. This problems a mostly caused by policy uncertainties, such as from bureaucracy, tax, corruption. Furthermore, these Problems are rooted from the Political transition to democratic regime, Big-bang decentralization (authority vs. responsibility) and financial crisis, which has limited the government power. This is because the crises increases government debt services cost and limit the power of central government. Lastly, most of regions rely on central governments transfers, to take any progressive policy and in many cases it comes with unnecessary new tax and retribution.

More so, the fiscal instruments in Indonesia were guided by constitution, which gives the central government the power to assess and collect all taxes due to the government. The regional and local governments are left with the powers to collect other fees. The main types of tax revenue for central and local governments are listed below as content in the 2000 constitution (appendix ii). The role of tax administration and revenue collection functions are performed by different institutions within the two tiers of government. At the central government level, Ministry of Finance, the taxation department are responsible for the administration of tax laws and revenue collection at the central level. Also, the revenue committee for local governments and Finance Department are responsible for tax matters at the local government level.

\section{Assessment Tax Evasion in Indonesia}

Taxation plays central role in promoting sustainable development, and Indonesia as a developing countries face significant challenges in developing their tax capacities and mobilizing domestic resources. Government consider to revenue from corporate income because almost $90 \%$ of tax revenues are derived from Multi National Enterprises. In the fact that MNCs appeals to codes of conduct, they have also sought to increase profits and gain competitive advantages through bribery and corruption. Corrupt practices are widely perpetuated by MNCs operating. Government from developing countries should be forced to discontinue business with operations involved in predatory financial practices (Otusanya O. J., 2012). The Indonesia government has already jailed multinational executive to enforce tax compliance. Most of them found guilty of evading Indonesian corporate taxes totalling IDR 13.6 billion (\$1.07 million) (Mcbride, 2015). Indonesia's tax administration was have many weakness. Poor legal and governance framework, shortcoming in organizational and staffing arrangements, ineffective tax payer services and enforcement programs and outdated information systems combined to severely reduce in large amounts of foregone tax revenue due to non-compliance by taxpayers.

\section{a. Assessments Anti avoidance Rules In Indonesia}

Government attempts to improve the tax compliance in Indonesia such as sunset policy, which is not matched by the comprehensive regulation of the schemes of tax avoidance schemes. Indonesia tax law contains a number of specific anti avoidance provisions. The obey provision that clearly mentions combating illegal tax avoidance is art 32 A of the income tax law, which grants the government powers to enter into international treaties. In Indonesia, treaties generally take precedence over domestic law provisions. The article provides that: In efforts of promoting economic and trade relationship with other countries, it is necessary to have a special set of law (lax- specialist) which regulates the taxing rights of each country covered in the law to provide legal certainty, to avoid double taxation and to prevent tax evasion. The form and substance of such law refer to the international convention, other regulations, and also the national regulation of each country. The main specific anti-avoidance rules in Indonesian tax law are contemplated in Act 18 and 4 of the income tax law. These cover articles: 
a) Debt to equity ratios, i.e. thin capitalization rules

b) Constructive dividends

c) Foreign Controlled corporations, and

d) Transfer pricing and advance pricing agreements.

Generally, the Indonesian tax authority will only issue regulations or circulars to attack specific modes of tax avoidance practices that it detects as taking place frequently and deems to be unacceptable. Such un-codified regulations and circulars include circulars on (i) the interpretation of term "beneficial owner" in relation to dividends, (ii) interest and royalties paid to non-resident taxpayers from tax treaties countries, and (iii) uni-lateral increase of withholding tax on interest paid to Netherland tax payers, and (iv) private rulings on what non-interest bearing are permitted.

\section{b. Substance Over form Principle}

Regarding legal or not legal of tax avoidance is based on fact and substance. The substance over form rule are based article 4, 23 and 26 of Indonesian Income Tax Law that:

"Any increase in economic capacity received by or accrued by the taxpayer from Indonesia as well as from offshore, which may be utilized for consumption or increasing the taxpayer's wealth, in whatever name and form including

The above provision forms the principle in determining taxable income, and it operates as one of the measures to counter tax avoidance and /or tax evasion. There are two factors a particularly relevant to the application of the substance over form principle in Indonesia

First, the income tax law define "taxable income" to include income" in whatever name of form". This is a broad definition. It means that under the income tax law, tax can be imposed on any economic gain received or earned by a taxpayer that can be used for consumption of for increasing the taxpayer's wealth. Whether the taxpayer has had an economic gain, rather than with the gains' particular source. It assumes that the earning or receiving of an economic gain is the best possible measure of the appropriate level at which the tax payer should contribute to government funds.

Secondly, in accordance with art 28 of the general provisions and procedures of taxation law, unless the tax regulations require otherwise, all tax records and bookkeeping shall follow Indonesian accounting standards. These standards apply the substance over form principle.

\section{c. Need for Indonesian General Anti-Avoidance Rule}

The substance over doctrine informs Indonesian tax law. It also has a range of specific anti avoidance provisions. However, these measures alone are not sufficient to combat tax avoidance in Indonesia. A general anti avoidance rule by definition would operate more generally than specific anti avoidance provisions. It would also serve to underline the importance of substance over form principle in Indonesia Law. Indonesia needs its own general anti avoidance tools, in order to more comprehensively combat improper tax avoidances that significant erode tax revenue.

Although the Law on income tax law amendment Act 36 of 2008 adding a few paragraphs of Article 18 of the tax avoidance schemes and the legal consequences of the preparation of the scheme. But anti-avoidance rules such as thin capitalization, special 
relationship and CFC unchanged. This can cause a loss for the country, because such the arrangements can easily anticipated by the taxpayer.

General anti-avoidance the prevailing in Article 18 of Income Tax Act as an antiavoidance measure general statute based, providing criteria of general application, i.e. not aimed at specific taxpayers or transactions to combat perceived tax avoidance. Antiavoidance rules in the Income Tax Law Article 18 regulates the types of specific types of tax evasion and focused on the certain taxpayers who do such tax evasion. In other words, the settings are not as the articles of safety in anticipation of abuse of law alone (Prebble, 2009).

\section{CONCLUSION}

In conclusion, there is need for a strong framework that will balance the need for sovereign states to protect their tax revenues from aggressive tax avoidance and evasion. This is because the provision of basic infrastructures is quite necessary for development and growth of any society. These infrastructures actually require a lot of money which just a single individual cannot provide. Tax evasion has the effect of distorting the principle of perfect market resource allocation with rippling effects on the state of the infrastructure. Therefore, the government shows great concern for a medium through which fund can be made available to achieve their set goals for the society. One of the means by which fund is derived is through taxation. Therefore, the citizens are expected to discharge their civic responsibility by paying their taxes as these contribute to the development and administration of the society at large. However, the basic infrastructures which are supposed to be provided for the entire society are not available and/or are in a worrisome condition. Often times, the government complain and claim that tax evasion contribute in a great extent to this failure. The government should have a great concern to explore more all about tax evasion case particularly focused on the certain taxpayers who do such tax evasion.

Furthermore, policy measures are required to redress the distortions that have arisen as regard to the taxation system of these two countries that left their nationally based tax regimes floundering. Taxpayers make use of aggressive tax planning strategies because they are able to operate in the legal vacuum that exists within the state as in the case of tax avoidance, and because the current regimes for handling the use of transfer pricing mechanisms. Such policy should tackle problems associated with the rapid integration of the global financial services industry, thus increased the need for the international community to address the issue of whether it is acceptable for sovereign states to provide the means for non-resident citizens and corporate entities to circumvent the tax and regulatory regimes of their own countries

The following recommendations are been suggested

1. Sustainability improvement in term of tax compliance is very important. Government endeavors to enforce the taxation law in a good system that it is fair for all citizens. Improve the tax compliance in Indonesia such as sunset policy, which is not matched by the comprehensive regulation of the schemes of tax avoidance scheme with contains a number of specific anti avoidance provisions.

2. The government should sought at ensuring the accountable and transparent in administration of the society.

3. Strengthen power should be made at sensitizing the populace on the seriousness of tax evasion and penalties attached (Fagbemi , Uadiale, \& Noah, 2010).

4. There is necessary in-depth study on tax evasion in the Islamic perspective about tax evasion by academician and researcher. 


\section{REFERENCES}

Atosanya, A. j. (2014). Anti Social Financial Practices in Negeria ;significant other perceptions. Journal of Financial Crime, Vol.21 149-173.

Azrina, N., \& Lai ling, M. M. (2014). An integrative Model in Predicting Corporate Tax Fraud. Journal of Financial Crime , 424-432.

Barry, A. (1999). Examining Tax evasion and Money Laundering . Journal of money laundering control, 326-330.

Brondolo, J., Silvani, C., Le Borgne, E., \& Bosch, F. (2008). Tax Administration Reform and Fiscal Adjustment The case of Indonesia (2001-2007). IMF.

Chen, S., Chen, X., \& Shelvin, T. (2008). Are Familiy firms more or less tax aggresive?

Chen, X., Wang, X. N., \& Tang, O. X. (2014). Tax Avoidance and Firm Value;Evidence from China. Nankai Business Review International, 25-42.

Cristian, A., \& Hamptom. (2005). Tax Avoidance and Global development;an introduction. Accounting Forum, 245-248.

Elgaroshi, T., \& Samat Musa, A. (2013). Control of Income Tax Evasion. Australian Journal of Basic and Applied Sciences, 770-780.

Fagbemi , O. T., Uadiale, O. M., \& Noah, O. A. (2010). The Ethics of Tax Evasion; Perceptual Evidence from Nigeria. European Journal of Social Sciences, Vol.17, number 3.

Fagbemi, T. O., Uadiale, O. M., \& Noah, A. O. (2010). The Ethics of Tax Evasion; Perceptual Evidence from Nigeria. European Journal of Social Sciences.

James, S., \& Nobes, C. (1997). The EAconomic of Taxation. New York: Prentise Hall.

Kholbadalov, U. (2012). The relationship of corporate tax avoidance, cost of debt and institutionak ownership;Evidence from Malaysia. Atlantic Renew of Economics.

Mayer, T. F. (1989). A Game Theory Analysis of Taxation and Revolution: A Progress Report. Corolado: University of Colorado, Boulder.

Mc Gee, R., \& Gelman, W. (n.d.). Opinions of the tehics of Tax Evasion; A comprative study of the USA and Six Latin American Countries.

Mcbride, M. ( 2015, Februari 6). http://www.internationaltaxreview.com/Article/3425068/. Retrieved from Indonesia-Archive/Indonesia-jails-multinational-executives-toenforce-tax-com.

Mikesell, J. L. (2002). Fiscal administration. USA: Thomson Learning Inc.

OECD. (1998). On combating bribery of Foreign public officials in International Business Transactions. Paris: Directorate for Financial \& Entrerprice Affairs .

Otusanya, O. J. (2011). Corruption as an obstacle to development in developing Countries; a review of literature. Journal of Money Laundering Control, 387-422.

Otusanya, O. J. (2012). A Critical Examination of The Multinational Companies anti corruption Policy in Nigeria. Accounting Business and Public Interest.

Picur, R., \& Belkaouli, A. R. (2006). The Impact of beureaucracy, Corruption and tax Compliance. Review Accounting and FInance, 174-180.

Prebble, Z. (2009). Approaches to Tax Avoidance Prevention in Seven Asian Jurisdiction- A Comparison. Januari and Februari.

Prinz , A. (2010). A Moral Theory of Taxation. IIPF Congres UPSALA. Germany: Munster University.

Ritsatos, T. (2014). Tax Evasion and Compliance; from the neo classical paradigm to behavioral economics a review. Journal of Accounting and Organizational Change, 244 .

Simanjuntak, D. F., \& Sari, D. (2014). Peran Penghindaran Pajak dalam mengurangi Biaya Hutang dengan Komite Audit sebagai variabel Pemoderasi. Seminar AKuntansi Nasional ke 17 Mataram Lombok (p. 1). Lombok: IAI. 
Rahmawati: An Appraisal of the Tax Evasion..

Simmons, R. S., \& Cheng, T. (1996). Citizens' Attitudes Towards Tax Evasion in Hongkong . Asian Review of Accounting , 98-117.

Slehat, Y. A. (2009). The tendency Toward Tax Evasion in Jordan. Malaysia: UUM.

Wardana, S. (2015, Maret Tuesday). Retrieved from http:// www.tempo.co/ read/news/ 2015 /o1/27/o87638028/Penunggak-Pajak-Rp-136-Miliar-Tak-Beritikad-Baik.

Wiko. (2015, Maret 24, tuesday). Actua. Retrieved from http:// thekompasiana. blogspot.com/2ohttp://www.aktual.co/ekonomibisnis/indonesia-peringkat-ketujuhaliran-uang-ilegal. 